\title{
Synergistic Hydrolytic Activities on Palm Kernel Cake Using Cocktail Enzyme of Mannanase BS4 and Bromelain
}

\author{
Haryati $\mathrm{T}^{1}$, Vincent ${ }^{2}$, Sinurat $\mathrm{AP}^{1}$ \\ 1) Indonesian Research Institute for Animal Production, PO Box 221, Bogor 16002, West Java, Indonesia \\ ${ }^{2)}$ Atma Jaya Catholic University of Indonesia, Jl. Jenderal Sudirman No. 51, Jakarta, Indonesia \\ purringcats2001@yahoo.com.au
}

\begin{abstract}
The addition of the enzyme mannanase BS4 as a feed supplement improves the carbohydrate digestibility of palm kernel cake. There is a possibility that the addition of protease will increase protein digestion. Therefore, in this research the best composition of cocktail enzymes (mannanase BS4 and bromelain) to enhance the digestibility of carbohydrate and protein in PKC was determined. Mannanase BS4 enzyme was produced using solid substrate fermentation of Eupenicillium javanicum BS4 in coconut meal for seven days, then extracted with Na-acetate buffer $0.1 \mathrm{M} \mathrm{pH} 5.8$, and precipitated with $75 \%\left(\mathrm{NH}_{4}\right)_{2} \mathrm{SO}_{4}$. Bromelain was extracted from flesh, peel, centre part of pineapple fruits with phosphate buffer $0.1 \mathrm{M} \mathrm{pH} 7$ and precipitated with $75 \%$ $\left(\mathrm{NH}_{4}\right)_{2} \mathrm{SO}_{4}$. Activities of mannanase BS4 and bromelain enzymes were measured on $0.5 \%$ gum locust bean and $1.5 \%$ casein as the substrates, respectively. Synergistic evaluation was measured with mixture of PKC as substrate and cocktail enzymes of mannanase BS4 and bromelain at volume composition: $100: 0,75: 25,50: 50,25: 75,0: 100 \%$ at $\mathrm{pH} 5.8$ and $40^{\circ} \mathrm{C}$, as a requirement condition for enzyme activity. The highest protease activity was observed at bromelain extracted from pineapple flesh, followed by centre part and peel. Synergistic activity results showed that the best composition of mannanase BS4 was observed at 50:50\% which means 1.38:0.96 U activities. This composition gave the highest synergistic activity to produce amino acid and close to reducing sugar yield with the one from 100\% BS4.
\end{abstract}

Key Words: Endo B-Mannanase, Protease, Bromelain, Saccharification, Synergistic Activity, Palm Kernel Cake

\section{INTRODUCTION}

In Indonesia, the availability of main feed ingredients for poultry mainly relatively not enough, so it must be imported from other countries. Feed such as corn, soybean meal, and fish meal were imported from other countries such as America, Brazil, and China.

Palm kernel cake (PKC) is one of the oil palm plantations by-products that can be used as an alternative for feed ingredients, have a fiber content of $17.63 \%$ and $14.49 \%$ of crude protein, but currently is not widely used for poultry feed ingredient because of has low fiber and protein digestibility (Sinurat et al. 2013).

The low digestibility of PKC due to contaminated by kernel shell that containing higher lignocellulose compounds. Lignocellulose containing hemicellulose which are polymeric compounds of xylan, mannan (galactoglucomannan, galactomannan, and glucomannan), and galactans that resistant to cattle biological degradation and acid hydrolysis. Hydrolysis of mannan can be enhanced by treatment with milling process to expand the surface area, chemical alkaline treatment or treatment by enzymes. The enzymes that commonly used to break down these compounds is Endo-1,4- $\beta$-mananase.

The mannanase enzyme (EC 3.2.1.78) is produced by molds E. javanicum and known as $\beta$ - mananase. The enzyme breaks mannan by hydrolizing at $1,4-\beta-\mathrm{D}$ - manopiranosil bond, if works with $\alpha$-D-galactosidase (cut galactose branch), $\beta$-D-glucosidase (cut glucose at the end of the main chain), and $\beta$-D- manosidase (cut monomer mannose at the 
end chain) will produce monomers galactose, glucose, and mannose (Abdeshahian et al. 2009). Purwadaria et al. (2003) suggested that the $\beta$-mananase of E. javanicum has optimum activity temperature at $50^{\circ} \mathrm{C}$ and the optimum $\mathrm{pH}$ range between 5.4-5.8.

Bromelain is a proteolytic enzyme produced from Ananas comosus plants. Pineapple contains bromelain almost in every part of plant. Proteolytic enzymes known as proteases (EC 3.4.22.5) works by hydrolyzing the peptide bonds specifically to the amino acid phenylalanine, valine, arginine (Amid et al. 2011; Mulyono et al. 2013.)

The use of enzymes as feed additives in poultry rations is expected to increase the digestibility of feed ingredients thus improving efficiency of feed. Some studies have reported that the addition of the enzyme into the diet can increase the body weight gain, improve FCR and digestibility of nutrients, and reduce the amount of pathogenic bacteria in the digestive tract (Danicke et al. 1999; Hubener et al. 2002).

Sinurat et al. (2013) reported that the addition of mananase BS4 $150 \mathrm{U}$ for $1 \mathrm{~kg}$ PKC can improve the in vivo digestibility of dry matter from $51.1 \%$ to $56.8 \%$. Chong et al. (2008) suggested the addition of 2.3 HUT of protease (haemoglobin unit tyrosine base) improve $12.5 \%$ of protein digestibility in laying hens. The use of mannanase BS4 and bromelain mixture enzymes to improve fiber and protein digestibility has not been reported. This study was conducted to determine the best volume mixture mannanase BS4 and bromelain enzymes to increase fiber and protein digestibility on palm kernel cake.

\section{MATERIAL AND METHODS}

\section{The production and extraction of enzymes mannanase BS4}

BS4 mananase enzyme produced through fermentation of solid substrates in coconut cake using E. javanicum with $60 \%$ moisture content and the addition of 1.5 doses of minerals mixture. Fermentation was carried out in a flat bioreactor for 7 days at $32^{\circ} \mathrm{C}$. BS4 enzyme extraction was done by dissolving the fermented residue $(10 \% \mathrm{w} / \mathrm{v})$ in buffer $0.1 \mathrm{M}$ Naacetate $\mathrm{pH} 5.8$ and then the filtrate was precipitated by $75 \%$ of $\left(\mathrm{NH}_{4}\right)_{2} \mathrm{SO}_{4}$.

\section{Extraction enzyme bromelain}

Bromelain was extracted from the fruit, i.e. skin, hump/axis, and meat using $0.1 \mathrm{M}$ phosphate buffer $\mathrm{pH} 7.0$ at a ratio of $1: 1(\mathrm{~kg}: \mathrm{l})$. The extract was precipitated by $75 \%$ of $\left(\mathrm{NH}_{4}\right)_{2} \mathrm{SO}_{4}$ and then incubated overnight at $4^{\circ} \mathrm{C}$. Enzyme solution was centrifuged at $11180 \times \mathrm{g}$ for 10 minutes at $4^{\circ} \mathrm{C}$. Pellet was then dissolved in $0.1 \mathrm{M}$ phosphate buffer $\mathrm{pH} 7$ so that the concentration of the solution became $100 \times$ more concentrated.

\section{Mannanase activity assay}

Mannanase activity was assayed by mixing $0.5 \mathrm{ml}$ of an appropriately diluted enzyme solution with $0.5 \mathrm{ml}$ of $0.5 \%$ locust bean gum in $50 \mathrm{mM}$ acetic buffer $\left(\mathrm{pH} \mathrm{5.8)}\right.$ at $40^{\circ} \mathrm{C}$ for $30 \mathrm{~min}$. The reaction was stopped by the addition of $1.5 \mathrm{ml}$ dinitrosalicylic acid (Miller 1959). After 5 minute boiling, the amount of reducing sugars was determined spectrophotometrically at $540 \mathrm{~nm}$. Mannose was used as a standard. One unit was defined as enzyme which liberates $1 \mu \mathrm{mol}$ glucose or mannose per minute under the assay conditions. 


\section{Test of the synergistic activity}

Test of the synergistic activity carried out by first diluting the enzyme bromelain and mananase BS4 with $0.2 \mathrm{M}$ phosphate buffer $\mathrm{pH}$ 5.8. Both enzymes (mannanase BS4 and bromelain) and then mixed into McCartney bottles in accordance with the variation of the volume of the composition of 100:0 75:25; 50:50 25:75; 0: 100 and PKC substrate is added as much as $2.5 \mathrm{ml}$ of $2 \%$, into the total mixture of $5 \mathrm{ml}$. PKC and enzyme mixture were incubated at $40^{\circ} \mathrm{C}$ for 2 hours in a linear shaker bath. After incubation, $1 \mathrm{ml}$ of solution was added with $0.5 \mathrm{ml}$ of $15 \% \mathrm{TCA}$ and incubated at $25^{\circ} \mathrm{C}$ for 30 minutes. The solution was then centrifuged at $2000 \times \mathrm{g}$ for $10 \mathrm{~min}$ and $0.4 \mathrm{ml}$ of the supernatant was taken to be added with $1 \mathrm{ml}$ of $0.4 \mathrm{M} \mathrm{Na}_{2} \mathrm{CO}_{3}$ and $0.2 \mathrm{ml}$ Folin Cioucalteu reagent.

Four $\mathrm{ml}$ of remaining solution in McCartney bottles were transferred to a test tube then heated at $100^{\circ} \mathrm{C}$ for $10 \mathrm{~min}$ and centrifuged at $2000 \times \mathrm{g}$ for $10 \mathrm{~min}$. $0.5 \mathrm{ml}$ of supernatant then were added with $0.5 \mathrm{ml}$ of distilled water and $1.5 \mathrm{ml}$ of DNS. The solution was heated at $100^{\circ} \mathrm{C}$ for $10-15$ minutes.

For amino acid assay control carried out by mixing the enzyme into a $2 \mathrm{ml}$ vial with a total volume of $0.5 \mathrm{ml}$ of enzyme mix (similar to sample various concentrations). $0.5 \mathrm{ml}$ $15 \%$ TCA was added to the vial containing enzyme mixture and incubated at $25^{\circ} \mathrm{C}$ for 30 minutes. After incubation then were added with $0.5 \mathrm{ml}$ of $2 \%$ of BIS substrate and then centrifuged at $2000 \times \mathrm{g}$ for 10 minutes. $0.4 \mathrm{ml}$ of supernatant was added with $1 \mathrm{ml}$ of 0.4 $\mathrm{M} \mathrm{Na} \mathrm{CO}_{3}$ and $0.2 \mathrm{ml}$ of Folin Cioucalteu reagent.

Reducing sugar assay control was done by mixing the enzyme in a test tube with a total volume of a mixture of $2.5 \mathrm{ml}$ (concentration variation similar to the sample). Then the solution was heated at $100^{\circ} \mathrm{C}$ for 10 minutes and added to the substrate BIS $2 \%$ as much as $2.5 \mathrm{ml}$ and then 10 minutes at $100^{\circ} \mathrm{C}$. Solution then was centrifuged at $2,000 \times \mathrm{g}$ for $10 \mathrm{~min}$. $0.5 \mathrm{ml}$ of the supernatant was taken and added with $0.5 \mathrm{ml}$ of distilled water and $1.5 \mathrm{ml}$ of DNS. The solution was reheated to $100^{\circ} \mathrm{C}$ for $10-15$ minutes. Data fiber and protein hydrolysis activity BIS taken into account by reducing the levels of each sample reaction products with control reactions.

\section{RESULTS AND DISCUSSION}

Table 1. Protease activity of the extract from the fruit of papaya and pineapple

\begin{tabular}{|c|c|c|c|}
\hline Part of papaya fruit & $\begin{array}{l}\text { Activity papain act } \\
\mathrm{U} / \mathrm{ml}\end{array}$ & Part of pineapple fruit & $\begin{array}{c}\text { Bromelain act } \\
\mathrm{U} / \mathrm{g}\end{array}$ \\
\hline Peel & 7 & Peel & 28.1 \\
\hline Flesh & 3 & Axis & 6393 \\
\hline Leaves/stem & 1 & Flesh & 7018 \\
\hline \multirow[t]{2}{*}{ Latex } & 18000 & & \\
\hline & & $\begin{array}{c}\text { Commercial bromelain } \\
\text { (GGP) }\end{array}$ & $\begin{array}{l}1000-1400 \\
\text { CDU/mg }\end{array}$ \\
\hline
\end{tabular}

Analysis of the enzyme content of some parts of the papaya and pineapple showed that the latex of papaya contains papain with very high activity, whereas bromelain enzyme assay was conducted in three parts pineapple fruit, i.e. peel/skin, axis and flesh. The results showed the highest protease activity was detected in the axis and flesh section, Mulyono et al. (2013) also reported that the highest protease activity was detected in flesh section. Purification of enzyme from pineapple fruit indicated that the type of enzymes found in both parts of the pineapple is different. Hump contains three types of enzymes, 
namely bromelain hump, ananain, and comasain. In the pineapple contains two different types of enzymes, namely flesh fruit bromelain and stem bromelain (Rowan et al. 1990). Bromelain hump differs from flesh fruit bromelain, although the fruit was found similar to the fraction of the enzyme bromelain hump. The high value of proteases in the flesh fruit may be related to the higher fruit bromelain. The protease assay results are also influenced by impurities such as polysaccharides, pigments, and phenolic compounds can reduce the activity of the enzyme. Phenolic compounds such as antioxidants may interfere with the plant protease assay, because its structure can be measured as phenolic amino acids (Ketnawa et al. 2009; Upadhyay et al. 2010; Jamaluddin et al. 2015).

The optimum $\mathrm{pH}$ and temperature of mananase BS4 were 5.8 and of $50^{\circ} \mathrm{C}$ (Table 2). Purwadaria et al. (2003) stated mananase BS4 from E. javanicum have optimum pH 5.4-5.8 and optimum temperature of $50^{\circ} \mathrm{C}$. Evaluation of the activity was then performed on the chickens body temperature is $40^{\circ} \mathrm{C}$, because this condition is more suitable for applications in the field.

Table 2. $\mathrm{pH}$ and optimum temperature of mannanase BS4 and Bromelain

\begin{tabular}{lcc}
\hline \hline Enzyme & $\mathrm{pH}$ & Temperature \\
\hline Mannanase BS4 & 5.8 & $50^{\circ} \mathrm{C}$ \\
Bromelain & 7.0 & $70^{\circ} \mathrm{C}$ \\
\hline
\end{tabular}

The bromelain from pineapple fruit extract has optimum activity at $\mathrm{pH} 7.0$ and temperature of $70^{\circ} \mathrm{C}$. This is consistent with the statement Mulyono et al (2013) which states that the optimum temperature is $70^{\circ} \mathrm{C}$ of bromelain, Liang et al. (1999) also reported that the optimum $\mathrm{pH}$ of bromelain range of 6.8-9.0 with the highest activity at $\mathrm{pH}$ 7.0. When bromelain will be mixed with BS4, one should pay attention to character of BS4 that is more active at lower $\mathrm{pH}$. Application as a poultry feed additive must also consider the environmental $\mathrm{pH}$ conditions of the digestive tract and the body temperature of birds. The assay of bromelain activity at $\mathrm{pH} 5.8$ and temperature of $40^{\circ} \mathrm{C}$ allows this enzyme to be used. However, the decrease in the enzyme activity under optimum condition can be covered by increasing the amount of enzymes that can act as a feed additive.

The formation of reducing sugars and amino acids results from hydrolysis activity of single BS4 enzyme and bromelain, and enzyme mixture on PKC substrate shown in Figure 1 and 2. The mannanase BS4 showed degradation activity in fiber and protein. Bromelain showed degradation activity on protein but not on fiber.

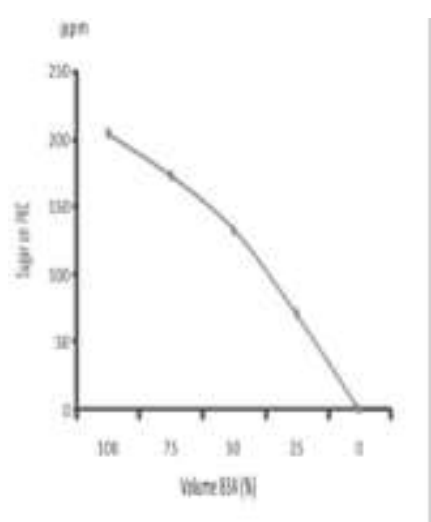

a

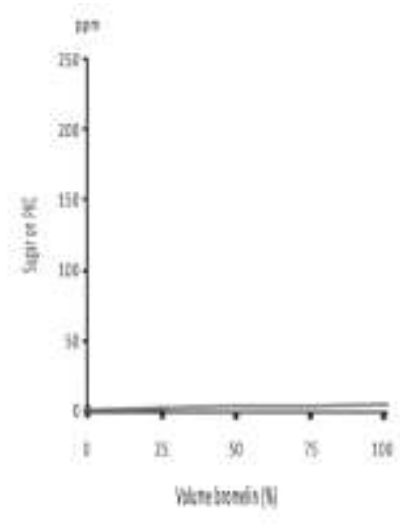

b

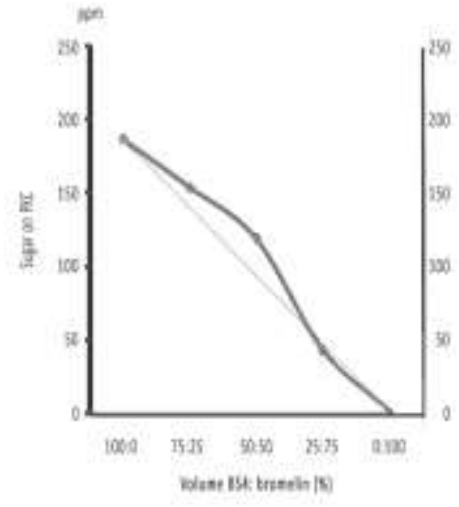

c

Figure 1.Curve of reducing sugar of PKC that degraded by BS4 (a), bromelain (b), a mixture of enzymes (c) at various volumes 


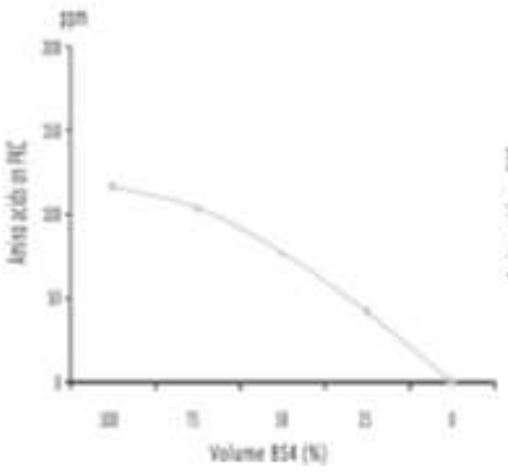

(a)

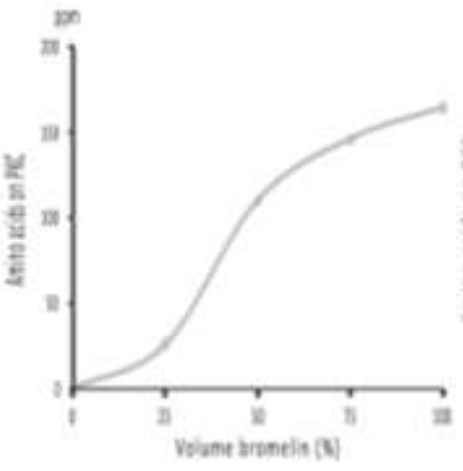

(b)

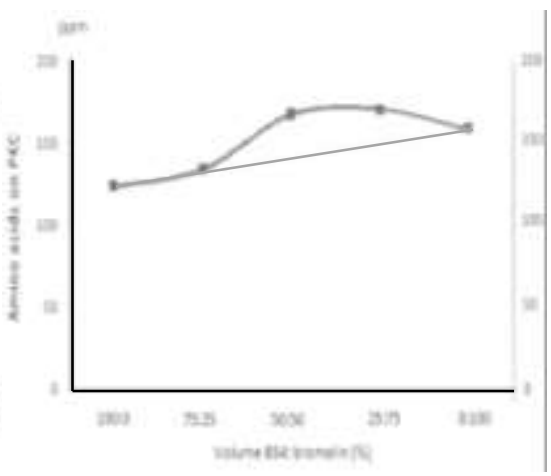

(c)

Figure 2. Curve of amino acids of PKC that degraded by BS4 (a), bromelain (b), a mixture of enzymes (c) at various volumes

In single enzyme activity assay of $50 \%$ volume, it showed protein degradation activity, but there was no fiber degradation activity. Zarei et al. (2012) suggested the addition of bromelain on PKC can hydrolyze up to $76 \%$ of the protein so that it can increase the digestibility of amino acids in the PKC. The use of bromelain have shortcomings because it can not improve the digestibility of the fiber and if applied in feed poultry, the energy fiber from PKC can not be fully utilized, as it can not digest the the fiber of PKC in the form of NDF (Oluwafemi 2008; Sinurat et al. 2013; Sharmila et al. 2014 ).

Mananase BS4 has fiber degradation activity so that applications on PKC substrate can produce reducing sugars (Figure 1). Reducing sugar is the result from hemicellulose and cellulose hydrolysis of PKC. The enzyme bromelain has protein degradation activity that can be applied to the PKC substrate. Bromelain has an active site cysteine peptide bond that can be hydrolyzed through nucleophilic system (Bhattacharyya et al. 2008). The results of this study indicate that the mananase BS4 have fiber and protein degradation activity on the substrate BIS. The formation of the BS4 protease activity may take place, because the substrate coconut meal contains protein, however protease is not a major enzyme.

The synergistic activity evaluation on reducing sugar formation of $\mathrm{PKC}$, fiber degradation activity on a mixture of different enzymes with the degradation activity on individual enzyme. On 50:50\% volume ratio of mananase BS4 and bromelain enzyme mixture that equals to 1.38:0.96 $\mathrm{U}$ activities produced $119 \mathrm{ppm}$ of reducing sugar, but on a single BS4 enzyme, it produced 133 ppm of reducing sugars. A decrease in the formation of reducing sugar was due to the possibility that mannanase BS4 enzyme which is a protein might be degraded by the bromelain which is a protease. Nevertheless, the addition of enzymes BS4 remained fairly helpful. Formation of BS4 reducing sugar curve in Figure 1 shows that the concentration of the enzyme addition start at $75 \%$ volume were approaching the optimum activity. While at 75 and $100 \%$ volume do not form a linear line with the lower volume enzyme. The synergistic activity of amino acid formation in volume $50 \%$ of single enzyme mananase BS4 produced amino acids $77 \mathrm{ppm}$, while the bromelain enzyme produced amino acids of $110 \mathrm{ppm}$. If both enzymes were mixed, they produced amino acid of $167 \mathrm{ppm}$. The amount of amino acid was lower than if that produced by each single enzyme were summed, this may be related to the limitations of the substrate compared to the number of amino acid of the enzyme separately $(77+110)$ because the BS4 protease and bromelain have the same substrate resulting in competition substrate binding. The presence of the synergistic activity in the enzyme mixture supporting arguments, stating that both enzymes can be used to improve the digestibility of fiber and protein of PKC. 


\section{CONCLUSION}

Mannanase BS4 and bromelain mixture enzymes have synergistic activity on the palm kernel cake substrate. The best composition of these two enzymes that are in 50:50\% volume ratio which is equivalent to the activity of 0.96 units bromelain and 1.38 units saccharification of BS4. This composition produces the highest of amino acids and reducing sugars that comparable with hydrolysis by $100 \%$ mananase BS4. For applications in poultry, in vivo digestibility trials are requiered to prove the synergistic activity of BS4 and bromelain in feed formulations.

\section{REFERENCES}

Abdeshahian P, Samat N, Hamid AA, Mohtar W, Yusoff W. 2010. Utilization of palm kernel cake for production of $\beta$-mannanase by Aspergillus niger FTCC 5003 in solid substrate fermentation using an aerated column bioreactor. J Industr Microbiol Biotechnol. 37:103-109.

Amid A, Ismail NA, Yusof F, Salleh HM. 2011. Expression, purification, and characterization of a recombinant stem bromelain from Ananas cosmosus. Elsevier. 46:2232-2239.

Bhattacharyya BK. 2008. Bromelain: An overview. IJNPR. 7:369-363.

Chong CH, Zulkifli I, Blair R. 2008. Effects of dietary inclusion of palm kernel cake and palm oil, dan enzyme supplementation on performance of laying hens. J Anim Sci. 21:1053-1058.

Danicke S, Vahjen W, Simon O, Jeroch H. 1999. Effects of dietary fat type and xylanase supplementation to rye-based broiler diets on selected bacterial groups adhering to the intestinal epithelium on transit time of feed, and on nutrient digestibility. Poult Sci. 78:12921299.

Hubener K, Vahjen W, Simon O. 2002. Bacterial responses to different dietary cereal types and xylanase supplementation in the intestine of broiler chicken. Arch Tierernahr. 56:167-87.

Jamaluddin MJA, Azmi AS, Sulaiman S, Jimat DN, Ezza M, Othman F, Amid A. 2015. Economic and environmental evaluation of recombinant enzyme production. In: Recombinant Enzymes From Basic Science to Commercialization. Amid A, editor. Basel (Switzerland): Springer International Publishing. p. 129-142. DOI 10.1007/978-3-319-12397-4_9.

Ketnawa S, Sai-ut S, Theppakorn T, Chaiwut P, Rawdkuen S. 2009. Partitioning of bromelain from pineapple peel (Nang Lae cultv.) by aqueous two phase system. Asian J Food Agric Ind. 2:457-468.

Liang HH, Huang HH, Kwok KC. 1999. Properties of tea-polyphenol-complexed bromelain. Elsevier. 32:545-551.

Miller GL. 1959. Using of dinitrosalicylic acid reagent for determination of reducing sugar. Anal Chem. 31:426-428.

Mulyono N, Rosmelia E, Moi JGP, Valentine BO, Suhartono MT. 2013. Quantity and quality of bromelain in some Indonesian pineapple fruit. IJABPT. 4:235-240.

Oluwafemi R. 2008. Palm kernel cake (PKC) utilization in monogastric animal feedingimplication for sustainable livestock development. J Vet Med. 6. Avaliable at: http://www.ispub.com/IJVM/6/2/5211 [cited 21 July 2015].

Purwadaria T, Haryati T, Frederick E, Tangendjaja B. 2003. Optimation of $\beta$-mannanase production on submerged culture of Eupenicillium javanicum as well as $\mathrm{pH}$ and temperature enzyme characterizations. JITV. 8:45-54.

Rowan AD, Buttle DJ, Barret AJ. 1990. The cystein proteinase of the pineapple plant. Biochem J. 266:869-875. 
Sharmila, Alimon A, Azhar AR, Noor K, Samsudin AA. 2014. Improving nutritional values of palm kernel cake (PKC) as poultry feeds: a review. J Anim Sci. 17:1-18.

Sinurat AP, Purwadaria T, Pasaribu T. 2013. Peningkatan nilai gizi bungkil inti sawit dengan pengurangan cangkang dan penambahan enzim. JITV. 18:34-41.

Upadhyay A, Lama JP, Tawata S. 2010. Utilization of pineapple waste: a review. J Food Sci Technol. 6:1-26.

Zarei M, Ebrahimpour A, Hamid AA, Anwar F, Saari N. 2012. Production of defatted palm kernel cake protein hydrolysate as a valuable source of natural antioxidants. Int J Mol Sci. 13:80978111. 